\title{
DESTINATION MANAGEMENT COMPANIES (DMCs) IN CROATIA AND THEIR IMPACT ON THE REDUCTION OF SEASONALITY
}

\author{
Maja Donadić ${ }^{1}$
}

\begin{abstract}
The tourism and hospitalityindustry faces a problem of seasonality everywhere in the world. Croatia as a tourist destination has a strong seasonality and it is recognized primarily as " The sun and the sea" destination. One of the possibilities to reduce the seasonality is a development of new tourism products in the periods out of peak season. An attempt to overcome the seasonality could be development of Destination Management Companies (DMCs), specialized receptive tourism agencies that create and place an offer of complex tourist products or packages, tailored to the needs of tourists, especially during periods out of peak season. This paper reviews these issues by analyzing the level of development of tourism products of Destination Management Companies (DMCs) in Croatia and their possible impact on the reduction of seasonality in Croatia.
\end{abstract}

Keywords: Destination Management Company (DMC), travel agency, seasonality, Croatia

\section{INTRODUCTION}

All tourist destinations are faced to some degree with the problem of seasonality, one of the inevitable characteristics of tourist demand. Seasonality is a temporal imbalance in the phenomenon of tourism, which may be expressed in terms of elements such as numbers of visitors, expenditure of visitors, traffic on highways and other forms of transportation, employment and admissions to attractions (Baum \& Lundtrop 2001, p.5).Croatia is recognized primarily as a destination of "The sun and the sea" product.Compared with the EU-28, Croatia's tourism activities are much more seasonal (Eurostat 2015). Strong seasonality has been present in Croatia for years. For examplethe strong seasonality wasrecorded in Croatia during the year 2012. The peak months of July and August accounted for $58 \%$ of nights spent in Croatian tourist accommodation establishments ${ }^{2}$, compared to EU level which was only $33 \%$ of nights spent in the EU, and July and August were also two peak months at EU level. In the same year the winter months from November to March had a share of nearly $25 \%$ of nights spent in EU, and in Croatia November-March period was far less significant and only accounted for $3.7 \%$ of the annual total of nights spent in Croatian tourist accommodation establishments (Eurostat 2015).

Monthly distribution of the total number of nights spent at tourist accommodation establishments, EU-28 and Croatia, 2012 (\%) can be seen in Figure 1. It shows strong seasonality which has been present in Croatia.

Public and private sector in tourism are interested in solving the problem of seasonalityand use pricing incentives and product varation in order to stimulate demand during shoulder and off-season periods (Baum \& Lundtrop 2001, p.2).Fernandez-Morales (2003) analyzed seasonal concentration in tourism demand series in three destinations in region Andalusia, Spain in the period of 20 years by means of Gini index. In all three analyzed destinations

\footnotetext{
${ }^{1} \mathrm{CEO}$ at Petros d.o.o., PhD student - Ekonomski fakultet Zagreb, Zagreb, Croatia.

2 Tourist accomodation establishments according to Eurostat statistics means: hotels and similar accomodation, holiday and other short-stay accomodation, camping grounds, recreational vehicle parks and trailer parks. It excludes provision of homes and furnished or unfurnished flats or apartments for more permanent use.
} 
the main tourist product was the "The sun and the sea', and Fernandez-Morales (2003) came to the conclusion that the destination where the tourist productwas the most diversified recorded the largest reduction of seasonality.Accordingly, in destination with the most diversified tourist producttourist nights in hotels were more evenly distributed over the year.

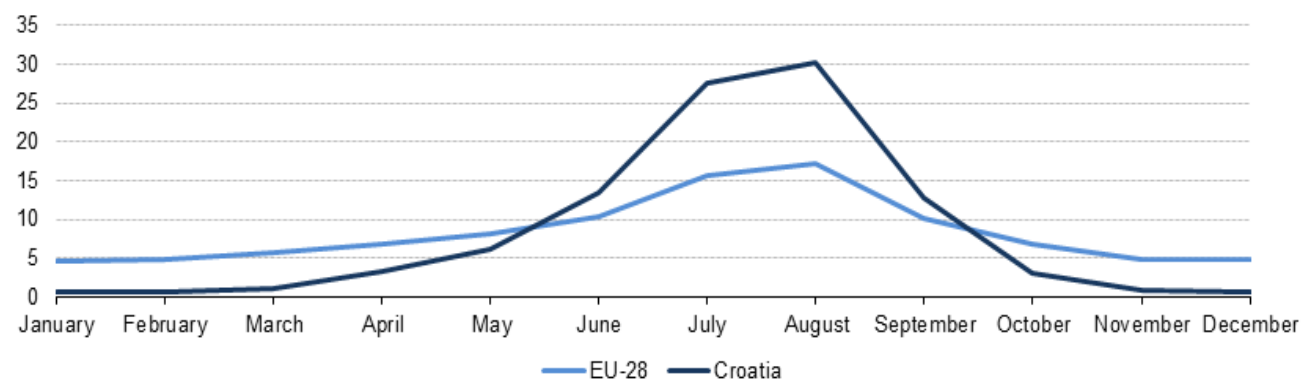

Fig.1. Monthly distribution of the total number of nights spent at tourist accommodation establishments, EU-28 and Croatia, 2012 (\%) Source: Eurostat

One of possibilitiesof addressing the problem of seasonality in Croatia could be more diversified tourism product that can meet the demands of today's tourists. Cavlek et al. (2010, p.201) state that experience has become nucleus of holidays. An integral part of the vision of Croatian tourism by 2020 is for Croatia to become a destination that offers to its guests hospitality, safety and a unique diveristy of various activities and experiencesall year round (Government of Republic of Croatia 2015). ${ }^{1}$

Destination management company (DMC) is one of the main actor in the provision of unique, authentic often personalized, year-round tourist products.

The aim of this paper is to analyze the development of tourism products ofDestination Management Companies in Croatia, with emphasis on those tourism products which Destination Management Companiesoffer in the period out of peak season and thereby contribute to the reduction of seasonality.

\section{DESTINATION MANAGEMENT COMPANIES (DMCs)}

Demands and needs of modern tourists are becoming increasingly complex and hence there is a need for more individualized and more diverse tourism products. To design, develop and implement increasingly complex, often personalized and specialized tourism products, there is a need for Destination Management Companies (DMCs) to operate. They have an overall knowledge of the destination and necessary resources to design, create and sell various tourism products in thedestination.

Association of Destination Management Executives, founded in 1995, defines the Destination Management Company (DMC) as a professional services company that has

\footnotetext{
${ }^{1}$ The vision for the development of Croatian tourism until 2020: "In the year 2020, Croatia is a globally recognizable tourist destination, competitive and attractive to investors, which creates new job openings and manages the development on its entire territory in a sustainable manner nurturing the culture of quality, and offering hospitality, safety and a unique diveristy of various activities and experiencesall year round" (Goverment of Republic of Croatia)
} 
extensive knowledge of the area in which operates, expertise and other resources, specializing in the design and implementation of events, activities, tours, transportation and program logistics(ADMEI 2015).

Euromic, the leading association of Destination Management Companies in Europe, founded in 1973, defines the Destination Management Company (DMC) as a company that provides a full range of services and must have extensive knowledge of destinations and in addition, experience, imagination, expertise, local contacts andsuppliers that are necessary to plan and execute the exclusive MICE programs as well as unique special interests programs (EUROMIC 2015).

The increasing specialization and offer individualization, in order to adjustto the requirements of the today's tourists, is not only present in small and medium-sized tour operators, but also with leading global tour operators.Many leading, small and mediumsized tour operators have begun a transformation or have already transformed their businesses in the direction of the Destination Management Companies (DMCs). Thus Kuoni Travel Group, which was founded back in 1906, and today is among the leading European tour operators, founded the strategic business unit Kuoni Destination Management. Kuoni DMCs network consists of over 70 wholly-owned Destination Management Companies (DMCs) and 20 sales offices throughout Africa, Arabia, Asia, Australia, Europe, India and the USA. (Kuoni Group 2015).

\section{Destination Managment Companies (DMCs) in Croatia}

Offer specialization and individualization among Croatian tour operators was encouraged by Ministry of Tourism in the year 2010. ${ }^{1}$ in order to adjustto the requirements of the today's tourists needs. As one of the measures of tourism policies in the Tourism Development Strategy of The Republic of Croatia until 2020.,is listed measureof development of specialized receptive travel agency (DMC - Destination Management Companies) which create and place complex tourism offers, i.e. holiday packages tailored to the needs and/or demands of tourists in specific market segments. DMCs are one of the key players in the diversification and standard increase of the total value of destination offer (Croatian Ministry of Tourism 2015) ${ }^{2}$.In accordance with the Tourism Development Strategy of The Republic of Croatia until 2020. (Croatian Ministry of Tourism 2015)tourism products in Croatia can be divided into dominant products and products with visible growth potential.

Dominant products:

1. The sun and the sea

2. Nautical tourism (yachting/cruising)

3. Business tourism

4. Cultural tourism

\footnotetext{
${ }^{1}$ Significant development of DMCc in Croatia was recorded in 2010 when the Ministry of Tourism in accordance with the program to encourage the creation,design and promotion of new tourism product in 2010. "Discover Croatia" awarded financial support to 36 travel agencies.

${ }^{2}$ The emphasis of the measure is on the development of the ability to create and place unique and memorable experiences and special interest tourist packages, especially in pre- and post-season periods, and in continental destinations.
} 
Products with visible growth potential:

1. Health tourism

2. Cycling tourism

3. Gastronomy and Oenology

4. Rural and mountain tourism

5. Golf tourism

6. Adventure and Sport tourism (diving, kayaking and canoeing, river rafting, adrenaline sports, shooting, fishing, winter sports and sport preparation)

7. Other products (Eco tourism, Youth tourism, Social tourism)

This paper analyze presence of these dominant products and products with visible growth potentialin the offer of 34 Destination Management of Companies (DMCs) in Croatia with the purpose to determine the development of the tourism product of Destination Management Companies (DMCs)in Croatia. Offer published on their websites was examined. From a total of 34 analyzed Destination Management Companies (DMCs), 29 of companieswere certified by the Association of Croatian Travel Agencies as DMCs specialists. ${ }^{1}$ Furthermore, 5 Destination Management Companies (DMCs)were analyzedthat were not certified by the Association of Croatian Travel Agencies as DMCs specialists, but were recognized by the Croatian National Tourist Board as potential candidates for the development of Destination Management Companies (DMCs) in Croatia (Croatian Tourism Board 2015). ${ }^{2}$ Offer of all DMC's in Croatia, which were certified by the Association of Croatian Travel Agencies as DMCs specialists (29 DMCs) and offer of all DMC's which were recognized by the Croatian National Tourist Board as potential candidates for the development of Destination Management Companies (DMCs) was analyzed. Presence of dominant products and products with visible growth potential offered by analyzed Destination Management Companies (DMCs) in Croatia is shown in Table 1.

\footnotetext{
${ }^{1}$ Specialization of tour operetors by topics, regions and niche markets is done by Association of Croatian Travel Agencies (UHPA). The objective of this specialization is to raise the quality and professionalism in the provision of services of DMCs in Croatia.

${ }^{2}$ The selection of potential candidates for the development of the DMCs and the granting of aid for programs of development and market introduction of complex tourism products for the market of special interest was done in 2014 and 2015 by Croatian Tourism Board. In year 2014. nine DMCs and in year 2015. seven DMCs were supported by Croatian Tourism Board. Some of these agency were Association of Croatian Travel Agencies DMCs specialists and therefore only additional 5 DMCs who were not Association of Croatian Travel Agencies DMCs specialsts but were supported by Croatian Tourism Board were analyzed in this papaer.
} 
Tab. 1. Presence of dominant products and products with visible growth potential offered by analyzed Destination Management Companies (DMCs) in Croatia

\begin{tabular}{|c|c|c|c|c|c|c|c|c|c|c|c|c|}
\hline & DMCs & \begin{tabular}{|c|} 
The \\
sun \\
and \\
the sea
\end{tabular} & $\begin{array}{l}\text { Nautical } \\
\text { tourism }\end{array}$ & $\begin{array}{l}\text { Health } \\
\text { tourism }\end{array}$ & $\begin{array}{l}\text { Cultural } \\
\text { tourism }\end{array}$ & $\begin{array}{l}\text { Business } \\
\text { tourism }\end{array}$ & $\begin{array}{c}\text { Golf } \\
\text { tourism }\end{array}$ & $\begin{array}{l}\text { Cycling } \\
\text { tourism }\end{array}$ & $\begin{array}{c}\text { Gastronomy } \\
\text { and } \\
\text { Oenology }\end{array}$ & $\begin{array}{c}\text { Rural and } \\
\text { mountain } \\
\text { tourism }\end{array}$ & $\begin{array}{c}\text { Adventure } \\
\text { and Sport } \\
\text { tourism }\end{array}$ & $\begin{array}{l}\text { Other products } \\
\text { (Eco-tourism, } \\
\text { Youth tourism, } \\
\text { Social tourism) }\end{array}$ \\
\hline 1 & Arx - Amber travel & & & & & & & & & & & \\
\hline 2 & Atlantis travel & & & & & & & & & & & \\
\hline 3 & Atlas Rabac & & & & & & & & & & & \\
\hline 4 & Dubrovnik travel & & & & & & & & & & & \\
\hline 5 & Eklata & & & & & & & & & & & \\
\hline 6 & E1-pi tours & & & & & & & & & & & \\
\hline 7 & Etno Art & & & & & & & & & & & \\
\hline 8 & Feral Tours & & & & & & & & & & & \\
\hline 9 & Fiore & & & & & & & & & & & \\
\hline 10 & Globtour Event & & & & & & & & & & & \\
\hline 11 & Gulliver travel & & & & & & & & & & & \\
\hline 12 & Huck Finn & & & & & & & & & & & \\
\hline 13 & Ilarija & & & & & & & & & & & \\
\hline 14 & Ilustris Travel DMC & & & & & & & & & & & \\
\hline 15 & Jadroagent & & & & & & & & & & & \\
\hline 16 & Katarina Line & & & & & & & & & & & \\
\hline 17 & Kompas Zagreb & & & & & & & & & & & \\
\hline 18 & Lang International & & & & & & & & & & & \\
\hline 19 & Marbis & & & & & & & & & & & \\
\hline 20 & Meridien Ten & & & & & & & & & & & \\
\hline 21 & M-G Express & & & & & & & & & & & \\
\hline 22 & Molaris Travel DMC & & & & & & & & & & & \\
\hline 23 & Olivari & & & & & & & & & & & \\
\hline 24 & Petros & & & & & & & & & & & \\
\hline 25 & RB travel & & & & & & & & & & & \\
\hline 26 & Receptiva opera & & & & & & & & & & & \\
\hline 27 & Shuttle travel agency & & & & & & & & & & & \\
\hline 28 & Sunturist & & & & & & & & & & & \\
\hline 29 & Šiloturist & & & & & & & & & & & \\
\hline 30 & Radmanove mlinice & & & & & & & & & & & \\
\hline 31 & Travelana & & & & & & & & & & & \\
\hline 32 & Uniline & & & & & & & & & & & \\
\hline 33 & Ventula travel & & & & & & & & & & & \\
\hline 34 & $\mathrm{VMD}$ & & & & & & & & & & & \\
\hline
\end{tabular}

The Sun and the Sea product was found to be the most common product inthe offer of Destination Management Companies (DMCs) in Croatia. Over 80\% of the analyzedDMCs had this product in their offer. Followed by Cultural tourism, which was offered by 24 DMCs, then Gastro and Oenology tourism offered by 20 DMCs, Adventure and Sport tourism offered by 18 DMCs, Nautical tourismoffered by 15 DMCs, Rural and Mountain tourism (13 DMCs), Cycling (12 DMCs), Health tourism (12 DMCs), Eco, Youth and Social tourism (11 DMCs), Business tourism (10 DMCs) and Golf tourism (1 DMCs). Number of analyzed DMCs who offered a certain tourist product can be seen in Figure 2. 


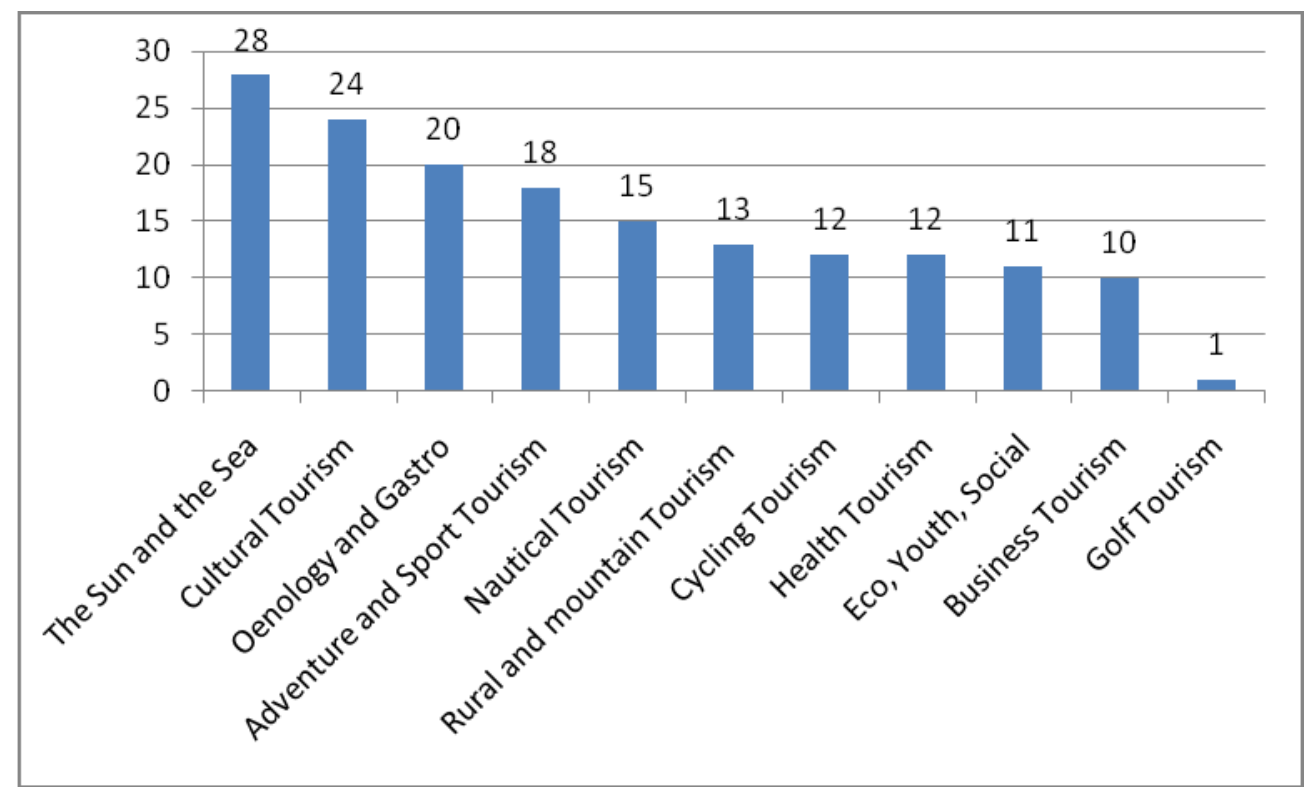

Fig. 2. Number of analyzed DMCs who offered a certain tourist product

Over $30 \%$ of the analyzed DMCs included in their offer at least one or more of these products: Rural and mountain tourism, Cycling tourism, Health tourism, Eco, Youth and Social tourism (the products with visible growth potential) ${ }^{1}$, and these product's cancontribute to reducation of seasonality of Croatian tourism as they are usually offered in periods outside the peak season. It should be noted that among the products with visible growth potential products: Eco, Youth and Social Tourism were analyzed together as "Other products". Among "Other products" Social tourism products were not found in the offer of the DMCs, while Youth tourism was far dominant among "Other products" category $(8 \mathrm{DMCs}){ }^{2}$ Golf tourism was offered only by 1 DMC. Gastro and Oenology tourism products as well as Adventure and Sport tourism products were offeredby over $52 \%$ analyzed DMCs.

\section{CONCLUSION}

Compared with the EU-28, Croatia's tourism activities are much more seasonal. One of possibilitiesof addressing the problem of seasonality in Croatia could be more diversified tourism product that could meet the demands of today's tourists. Given the needs of today's tourists these products are often complex, specialized, authentic and unique and can be created by a Destination Managment Comapny (DMC). Dominanat products (Bussines tourism, Cultural tourism and Nautical tourism) as well as products with visible growth potential (Health tourism, Cycling tourism, Oenology and Gastro tourism, Rural and

\footnotetext{
${ }^{1}$ Rural and mountain tourism (13 DMCs), Cycling tourism (12 DMCs), Health tourism (12 DMCs), Eco, Youth and Social tourism (11 DMC's).

${ }^{2}$ High presence of Youth travel in offer of DMCs is to some extent result of tradition of travel of elementary and high school students in Croatia and these travels are regulated by Croatian Ministry of Science, Education and Sports. Regulations about the trip, excursion and other educational activities outside school (Narodne novine 2015)
} 
Mountain tourism, Golf tourism, Adventure and Sport tourism, Eco and Youth tourism) are included in offer of Destination Management Comapanies (DMCs) in Croatia. Social tourism products are not included.

High share of the product The sun and the sea in the offer of Croatian DMCs indicates that there is a possibility for further specialization of Destination Management Companies (DMCs) in Croatia in the direction of special interest programs, organized out of the peak season, what would contribute to reduction of seasonality in Croatia.

Further research could be focused on the investigation of the degree of specialization of Croatian Destination Management Companies (DMCs) and the success of DMCs product's sales in the periods out of the peak season, and thus the impact on the reduction of seasonality.

\section{REFERENCE}

Book

1. Baum, T., Lundtorp, S. (2001). Seasonality in Tourism. Oxford: Elsevier Science Ltd.

2. Čavlek, N.(1998). Turoperatori i svjetski turizam. Zagreb: Golden Marketing

3. Kotler P. (2006). Marketing for Hospitality and Tourism. New Jersey: PearsonPrentice Hall, Journal Article

4. Čavlek, N., Matečić I., Ferjanić Hodak, D. (2010). Pokretači inovacija u turizmu: Neki teoretski i praktični pristupi. Acta turistica, Volume (22), Page number (201220)

5. Fernandez-Morales, A. (2003). Decomposing Seasonal Concentration. Annals of Tourism Research, Volume (30), Page number (942-956).

Website:

http://www.ambertravel.net (2.8.2015.)

http://atlantis-travel.hr/(2.8.2015.)

http://www.atlas-istra.hr/(2.8.2015.)

http://www.dt-croatia.com/(2.8.2015.)

http://www.eklata.com/(2.8.2015.)

http://www.elpi-tours.com/(8.8.2015.)

http://www.etnoart-travel.com/(8.8.2015.)

http://feral-tours.com/(8.8.2015.)

http://fiore.hr/(8.8.2015.)

http://www.globtour.hr/(8.8.2015.)

http://www.gulliver.hr/ (8.8.2015.)

http://www.gulliver-premium.com/(8.8.2015.)

http://www.huckfinncroatia.com/new/(8.8.2015.)

http://ilirijabiograd.com/ (9.8.2015.)

http://www.illustris-travel.com/(9.8.2015.)

http://travel.jadroagent.hr/(9.8.2015.)

http://www.incomingcroatia.com/(9.8.2015.)

http://croatia-lang.com $(9.8 .2015$.

http://www.marbis.hr/hr(9.8.2015.)

http://www.meridienten.com/(9.8.2015.) 
http://www.mgexpress.hr/(9.8.2015.)

http://www.island-krk-vacations.eu/(9.8.2015.)

http://www.olivari-travel.com/(9.8.2015.)

http://petros.hr/(9.8.2015.)

http://www.rbtravel-incoming.com/(9.8.2015.)

http://cubic.biz.hr/receptiva $(9.8 .2015$.

http://www.tastedalmatia.com/(9.8.2015.)

http://www.sunturist.com/(9.8.2015.)

http://siloturist.com/(9.8.2015.)

http://www.radmanove-mlinice.hr/index.php/hr/turisticka-agencija (9.8.2015.)

http://www.travelana.hr/ $(9.8 .2015$.

http://www.uniline.hr/croatia/ (9.8.2015.)

http://www.ventula-travel.com/ (10.8.2015.)

http://vmd.hr/ (10.8.2015.)

http://www.uhpa.hr/projekti/specijalizacije/dmk(2.8.2015.)

http://www.mint.hr/UserDocsImages/100722-upozn-rhII-b.pdf(2.8.2015.)

http://narodne-novine.nn.hr/clanci/sluzbeni/2013 $05 \quad 55 \quad 1119 . h t m l(2.8 .2015$.

http://www.uhpa.hr/documents/PDF/SPECIJALIZACIJE/KRITERIJI\%20ZA\%20SPECIJ

ALIZACIJE\%20DMK.pdf(2.8.2015.)

http://ec.europa.eu/eurostat/statistics-

explained/index.php/Travel agency and tour_operator_statistics - NACE_Rev._2

(2.8.2015.)

http://ec.europa.eu/eurostat/statistics-explained/index.php/Tourism statistics for Croatia

http://www.adme.org/dmc/what-is-a-dmc.asp (1.8.2015)

http://www.euromic.com/dmc.php (2.8.2015)

http://www.kuoni-dmc.com/en/about-us/about-us/global-network(2.8.2015.) 